\title{
Changes in Soil Microbial Activity and Community Composition as a Result of Selected Agricultural Practices
}

\author{
Martyna Głodowska*, Małgorzata Wozniak \\ Institute of Soil Science and Plant Cultivation-State Research Institute, Department of Agricultural Microbiology, \\ Puławy, Poland \\ Email: *glodowska.m@gmail.com
}

How to cite this paper: Głodowska, M. and Wozniak, M. (2019) Changes in Soil Microbial Activity and Community Composition as a Result of Selected Agricultural Practices. Agricultural Sciences, 10, 330-351. https://doi.org/10.4236/as.2019.103028

Received: January 15, 2019

Accepted: March 12, 2019

Published: March 15, 2019

Copyright $\odot 2019$ by author(s) and Scientific Research Publishing Inc. This work is licensed under the Creative Commons Attribution International License (CC BY 4.0).

http://creativecommons.org/licenses/by/4.0/

\begin{abstract}
For a constantly growing human population, healthy and productive soil is critical for sustainable delivery of agricultural products. The soil microorganisms play a crucial role in soil structure and functioning. They are responsible for soil formation, ecosystem biogeochemistry, cycling of nutrients and degradation of plant residues and xenobiotics. Certain agricultural treatments, such as fertilizers and pesticides applications, crop rotation, or soil amendment addition, influence the composition, abundance and function of bacteria and fungi in the soil ecosystems. Some of these practices have rather negative effects; others can help soil microorganisms by creating a friendlier habitat or providing nutrients. The changes in microbial community structure cannot be fully captured with traditional methods that are limited only to culturable organisms, which represent less than $1 \%$ of the whole population. The use of new molecular techniques such as metagenomics offers the possibility to better understand how agriculture affects soil microbiota. Therefore, the main goal of this review is to discuss how common farming practices influence microbial activity in the soil, with a special focus on pesticides, fertilizers, heavy metals and crop rotation. Furthermore, potential practices to mitigate the negative effects of some treatments are suggested and treatments that can beneficially influence soil microbiota are pointed out. Finally, application of metagenomics technique in agriculture and perspectives of developing efficient molecular tools in order to assess soil condition in the context of microbial activities are underlined.
\end{abstract}

\section{Keywords}

Agricultural Practices, Microbial Activity, Soil Microorganisms 


\section{Introduction}

Soil is considered a non-renewable natural resource and it is of great environmental concern to keep it in a healthy and productive state. Sustainable use of agricultural lands has become one of the main interests among researchers, policy makers and farmers [1]. However, in the concept of sustainable farming is rarely the importance of soil microbiota mentioned. Microbiological aspects of soil fertility are extremely important features; however, they are often underestimated or completely neglected. Bacteria and fungi are the organisms that play a key role in the soil formation, decomposition of organic matter, ecosystem biogeochemistry and cycle of nutrients [2] [3] [4]. The nutrient cycle is considered to be a critical ecosystem function essential to life. Some symbiotic microorganisms have a direct positive impact on crop productivity by increasing bioavailability of nutrients such as phosphorus (P) by arbuscular mycorrhizal fungi (AMF) [5] or P-solubilizing bacteria [6]. Also, nitrogen $(\mathrm{N})$ can be provided to the plant through biological nitrogen fixation (BNF) by soil bacteria such as rhizobium. The decomposition of organic matter into simpler molecules is another important service provided by soil microorganisms. It is estimated that up to $90 \%$ of degradation processes are carried out by bacteria and fungi [7]. Once the organic matter breaks down, excess nutrients such as N, P and S (Sulfur) are released into the soil and become available to the plants (Figure 1).

Microorganisms also play a very important role in the soil structure and aggregates formation [8], as well as functions related to plant health and pathogens suppression. In the soil system soil-born pathogenic bacteria and fungi are kept under control through competition, predation and parasitism by healthy soil microbial communities [9]. Some bacteria belonging to Pseudomonas spp. are known to be able to control plant diseases such as root-rot fungi by rapid root colonization, production of antifungal antibiotics and induction of systemic resistance in the plant [10]. Soil microorganisms are capable of degrading some pollutants and pesticides [11] which are vital for the functioning of agricultural systems. Therefore, it is essential to consider microbiological aspects in the concepts of sustainable land use and responsible agriculture. There is an urgent need for better understanding of the distribution and behavior of microbial communities and their functions in the soil as well as their response to agricultural treatments. Arable lands are highly disturbed through numerous treatments that affect soil physicochemical properties, soil structure and biological activity. Use of mineral fertilizers and pesticides in the intensive crop production causes many environment and health concerns. There are also reasons to believe that agricultural chemicals and intensive farming can negatively affect soil microbiota and reduce soil biodiversity.

On the other hand, there is some evidence suggesting that soil amendments such as green and animal manure, biochar as well as crop rotation (plant diversity) may improve soil microbial activity and diversity [12] [13] [14]. As it is already known, only a small portion of microorganisms are cultivable in in-vitro 


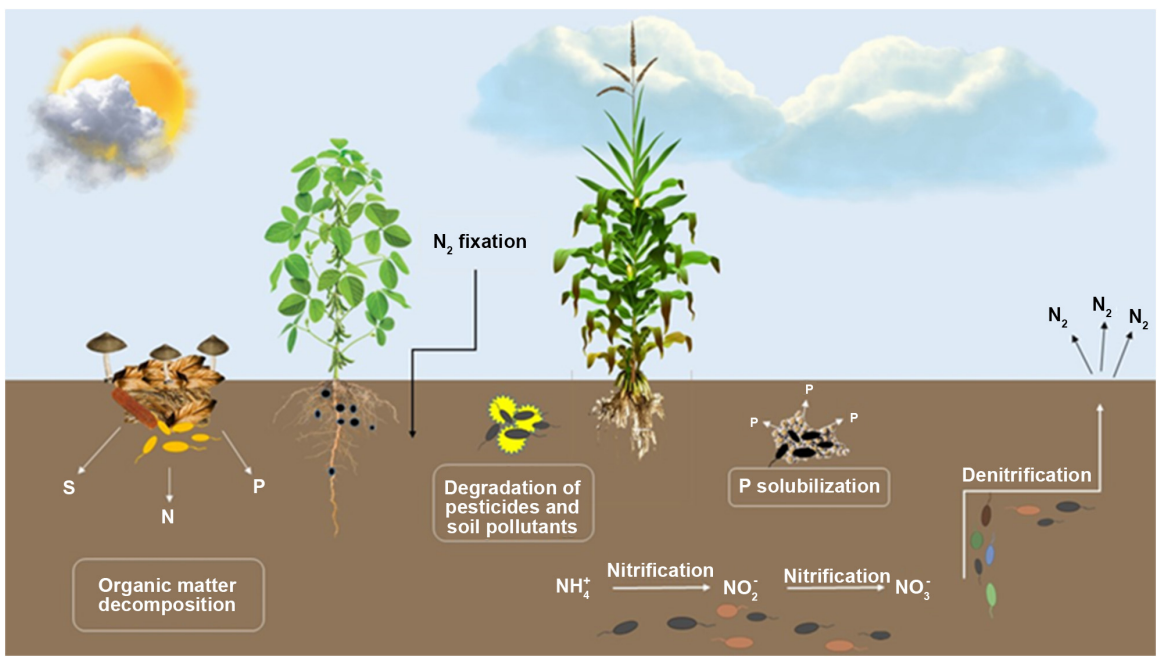

Figure 1. The role of microorganisms in the nutrient cycling in agricultural soils.

conditions. The development of metagenomics techniques opens all range of possibilities to identify and quantify soil microbiota directly from an environmental sample. We can better identify soil and rhizospheral microbial communities and understand how agricultural practices affect specific groups of microorganisms. Therefore, the main objective of this review is to discuss the response of soil microbiota to different agricultural treatments such as pesticides, fertilizers and soil amendment applications as well as plant rotation and GMO (genetically modified organisms) crop cultivation. The special focus is on the soil microbial activity which is an important indicator of soil health and fertility. Furthermore, the importance of metagenomic techniques in agricultural microbiology as a tool to better understand an impact of agriculture on soil microbial communities has been underlined.

\section{Effect of Selected Farming Practices on Soil Microorganisms}

A gram of soil contains billions of microorganisms and an undetermined diversity of them. It is estimated that a microbial diversity of soil might be composed of several hundreds or thousands different taxa [15]. Some estimations of the number of species of bacteria per gram of soil go as high as 8.3 million [16]. Although plant-microbe interactions and ecosystem functions have received much attention in ecology and agricultural sciences [17], the relationship between an abundance of microorganisms and their function become focus of scientists only recently. Less than $1 \%$ of microorganisms can be cultured in the classical plate count method [11]. Although culture-based techniques on single organisms may not give field relevant information about the soil functions, some of that research did provide valuable insights on some microorganisms e.g. rhizobia $\mathrm{N}$ fixation. Nevertheless, the pure-culture approach, although commonly used in environmental biology, seriously restricts the holistic image of the microbial communities colonizing the soil ecosystem. The soil ecosystem is believed to be 
the least understood among all ecosystems. Soil microbiology is still a challenge to scientists trying to understand the way microorganisms metabolize substrates, participate in the nutrient cycle and decompose organic matter.

It was shown that DNA concentration can vary from 0.1 to $7 \mu \mathrm{g} \cdot \mathrm{g}^{-1}$ in the agricultural soils using different extraction methods, which is lower compared to forest soils where DNA concentration can range from 0.1 to $35 \mu \mathrm{g} \cdot \mathrm{g}^{-1}$ [18]. Agricultural practices affect microbial activity in the soils, particularly in the soils with long agricultural history. Soil disturbance as a result of different agrotechnical treatments might be the reason why agricultural soils are microbiologically less rich compared to the natural undisturbed soils. Anthropogenic activities can directly or indirectly influence the function and diversity of microorganisms in the soil system [19]. Already decades ago, it was shown that different management systems affect soil microbial composition and abundance. Martyniuk and Wagner [20] showed using standard plate counts methods that microbial populations differ between growing systems. Microbial abundance was significantly lower for untreated soils, intermediate for the soils where chemical fertilizers were applied and higher on the plots treated with manure. In another study it was demonstrated that the biomass of bacteria in two agricultural soils were higher than in the natural shrubs formation while the biomass of fungi was higher in undisturbed natural soils compared to cultivated soils [21]. Tillage destroys the fungal hyphae network and incorporates organic waste into deeper layers of the soil; therefore, it affects negatively the fungi but increase the abundance of bacteria.

\section{Effect of Pesticides on Soil Microorganisms}

To sustain plant growth and protect the crops from diseases and pest infestations, use of pesticides is currently a very common practice. Pesticides are foreign substances in the soil environment, they might disturb microorganisms, affect their behavior and in consequence influence the cycle of nutrients and lead to serious ecological consequences [22]. Degradation pathways and mobility of pesticides depend on biotic and abiotic factors [23] and their lifetime in the soil is strongly related to their physical and chemical properties (Table 1). Many of commonly use pesticides have the capacity to accumulate and stay in the soil ecosystem or leach to the ground water [24]. Contamination with the pesticidal chemicals due to their non-target specification and mobility became one of the main environmental issues in agriculture. Pesticides can get to the soil systems directly from the plant treatment or with the plant organic matter which is later decomposed by the microorganisms. Many of the soil microorganisms have bioremediation qualities and are capable of degrading most pesticides in the soil [23]. A number of studies conducted on agricultural and forest soils demonstrated a positive correlation between the soil microbial biomass and the degradation rate of pesticides such as metribuzin, linuron, glyphosate, alachlor, 2,4-dinitroaniline and dicamba [25] [26] [27] [28]. It was suggested that microbial 
Table 1. Effect of selected pesticides on microbial activity.

\begin{tabular}{|c|c|c|c|c|}
\hline Pesticide & Type & Half-life in the soil ${ }^{\mathrm{a}}$ & Effect on soil microorganisms & Source \\
\hline \multirow[t]{2}{*}{ Glyphosate } & Herbicide & $>35$ days & $\begin{array}{l}\text { Stimulate soil microbial activity measured by } \mathrm{C} \text { and } \mathrm{N} \\
\text { mineralization. Do not affect soil microbial biomass }\end{array}$ & [42] \\
\hline & & & $\begin{array}{l}\text { Reduce microbial biomass at higher concentration }\left(3.84 \mathrm{~L} \cdot \mathrm{ha}^{-1}\right) \\
\text { Temporary inhibitory effect recommended field doses or higher }\end{array}$ & [43] \\
\hline Atrazine & Herbicide & 60 to 100 days & Decrease dehydrogenase activity & [44] \\
\hline Paraquat & Herbicide & 16 months to 13 years & Decrease dehydrogenase activity & [44] \\
\hline Captan & Fungicide & 10 days & Inhibits denitrifying bacterial activity & [45] \\
\hline \multirow[t]{2}{*}{ Cypermethrin } & Insecticide & 2 to 8 weeks & $\begin{array}{l}\text { At the rates } 10-80 \mu \mathrm{g} \cdot \mathrm{g}^{-1} \text { soil no significant effect on soil } \\
\text { enzyme activities ( } \beta \text {-glucosidase, urease, acid-phosphatase, } \\
\text { and dehydrogenase) }\end{array}$ & [46] \\
\hline & & & $\begin{array}{l}\text { Slightly toxic short-term effect on soil biomass, respiration and } \\
\text { FDHA activity at the recommended dose }\end{array}$ & [47] \\
\hline Acetamiprid & Insecticide & 16 days & $\begin{array}{l}\text { Strong negative effect on soil respiration and phosphatase } \\
\text { activity }\end{array}$ & [39] \\
\hline
\end{tabular}

biomass could be a suitable indicator of the soil pesticide degradation capacity [27]. Many researches have been conducted in order to assess the impact of pesticide on microbial communities, soil biomass, respiration, enzymatic activities and other microbial parameters which were reviewed by Chowdhury and colleagues [24]. Generally, most of the pesticides have rather negative impact on microorganisms and they decrease microbial biomass in the soils [29]-[35]. However, the effect of pesticides on the microbial structure and function depends on many factors. The most important factor among them, which can be controlled by the farmer, is the type of pesticide, dosage and time of application. The fluorescein diacetate hydrolyzing activity (FDHA) is a method which is widely used to assess the primary decomposers, bacteria and fungi activity [36]. Zelles et al. [37] using FDHA method, studied the effects of some herbicides (4-chloroaniline, atrazine, pentachlorophenol and chloroacetamide), fungicides (zineb and captan) and insecticides (4-nitrophenol and lindane) on the soil microbiota over 48 days. Atrazine, captan and lindane showed insignificant effect. The remaining pesticides induced changes in the activity of microorganisms. In most cases, higher concentrations of pesticides caused reversible or irreversible reductions of FDHA, while the low concentrations sometimes produced a stimulating effect.

Soil respiration, which is the metabolic activity of soil microorganisms quantified by $\mathrm{CO}_{2}$ evolution, is also used to assess pesticides effects on the microorganisms [24]. Soil respiration is considered to be an efficient bioindicator of microbial condition and of general soil health and quality. The degree of inhibition effect caused by the pesticides depends mostly on the intensity of the stress but also on the time of exposure to the pesticides [38]. Several studies have been conducted to investigate the impact of various pesticides on the soil respiration. The results showed a strong variation mostly between different application doses of a 
pesticide. Yao et al. [39] tested field concentration ( $0.5 \mathrm{mg} \cdot \mathrm{kg}^{-1}$ dried soil) and increased concentration ( 5 and $50 \mathrm{mg} \cdot \mathrm{kg}^{-1}$ dried soil) of acetamiprid on the soil enzymes activities and soil respiration. The results demonstrated that the pesticide had a strong inhibiting effect on the soil respiration and enzymes activities at the high application rate; however, no negative effect was recorded at the normal field concentration. Studies conducted by Bartha and colleagues [40] showed that initially, pesticides can increase $\mathrm{CO}_{2}$ production and subsequently, after a longer time period, decrease the $\mathrm{CO}_{2}$ evolution in the soil. On the other hand, certain investigations clearly demonstrated the pattern of increased $\mathrm{CO}_{2}$ evolution after treatment with different types of pesticides [35] [37] [41].

It was also shown that a much higher dose of pesticide compared to the normal field application rate would cause a temporary decrease of respiration rates in the agricultural soil; however the effect was of little ecological importance [31].

More accurate parameter to assess the degree of the disturbances in soil is the microbial metabolic quotient $\left(\mathrm{qCO}_{2}\right)$, which is the respiration rate per unit of biomass. This index is considered to be a more sensitive indicator of the toxicity than soil respiration or microbial biomass alone [48]. Anderson and Domsch [49] suggested that microbial $\mathrm{qCO}_{2}$ rises due to pesticide application which might force microorganisms to use more of their energy for the cell maintenance. Furthermore, Jones et al. [50] showed that the fungicide metalaxyl and the herbicide propachlor application on the soil from the arable and pasture ecosystem caused the disturbance of microbial metabolic quotient for 21 and 15 days respectively. Moreno et al. [51] conducted the research to investigate the effect of atrazine on microbial activity. He found that $\mathrm{qCO}_{2}$ was significantly higher in the soil treated with a higher dose of herbicide than those of untreated soil. Zhang et al. [52] studied phospholipid fatty acids (PLFAs) after foliar application of cypermethrin on the pepper phillosphere microbial community. The results demonstrated that the treatment significantly increased the total and bacterial biomass compared with the control; however, the fungal fatty acids importantly decreased after the pesticide application. DNA and RNA quantification method were used by Bælum, et al. [53] in an experiment where the herbicide was applied repetitively to the soil. The results showed that the population of microorganisms that could degrade the pesticide was increased. It could suggest that overall changes caused by the pesticides application are of minor importance perhaps due to fast adaptation of microbial communities to the changing conditions.

The influence of the pesticides on soil microbiota is a very complex process and it depends on multiple factors such as the pesticide structure and concentration, but also environmental factors such as temperature, moisture, soil $\mathrm{pH}$, type, salinity as well as the content of the organic matter [24]. Although most of studies show rather negative effect of pesticides on the soil microbiota, a better comprehension of the soil ecosystem and soil disturbance caused by the soil management is needed. To reduce the negative influence of pesticides on the soil 
microorganisms it is necessary to know the mechanisms of action and understand how it affects the microbial function and activities. Furthermore, most of the studies were performed in laboratory setups which poorly reflect real field conditions. To avoid the negative effect of pesticides on the soil microorganisms recommended application rates should not be exceeded.

\section{Effect of Fertilizers and Soil Amendments on Microorganisms}

In present days' crop production is almost impossible without the application of mineral fertilizers. Fertilizers can increase productivity and, in a result, increased quality of products in agricultural systems [54]. However, the overuse of fertilizers, which is often observed in modern intensive agriculture, is often the source of many undesirable effects on the environment as well as on human health. Moreover, organic as well as inorganic fertilizers can significantly affect structure and function of soil microbiota which is directly linked to soil fertility and health.

Numerous studies have been conducted to evaluate the effect of different types of fertilizers on soil microbiota. Since a long time, it is known that soil microorganisms respond to the organic matter introduced to the soil system [55]. Therefore, it was not unexpected that bacterial density, $\mathrm{CO}_{2}$ evolution and the enzymatic activities were significantly increased in poultry dung amended soils compared to untreated soil [56]. Likewise, Bol et al. [57] showed the positive effect of poultry slurry and farmyard manure on the enzyme activities in the temperate climate grassland. Zhong et al. [14] using PLAF soil profile demonstrated that long-term application of organic manure increases soil microbial biomass, activity and diversity. Lazcano and coworkers [13] compared the effect of mineral and organic (rabbit manure and vermicompost) fertilizers on microbial communities' structure and function. Results showed that manure led to a fast increase in the abundance of PLAF biomarkers for gram-negative bacteria compared to inorganic fertilizer. Also, microbial biomass was higher when the organic fertilizers were applied and generally manure-amended soils showed higher microbial activity than the inorganic fertilizer treatment at harvest time. Moreover, it was demonstrated that both manure and vermicompost increased activity of the soil enzymes that are responsible for degrading organic $\mathrm{C}, \mathrm{N}$ and $\mathrm{P}$ compounds between $12 \%$ and $22 \%$ compared to soils where, inorganic fertilizers were applied.

On the other hand, numerous studies report the negative effect of mineral fertilizers on soil microorganisms. In a literature review, Allison and Martiny [58] found that from 38 articles as much as $84 \%$ reported that microbial communities are sensitive to nitrogen $(\mathrm{N})$, phosphorus $(\mathrm{P})$ and potassium $(\mathrm{K})$ fertilizers. Some meta-analysis [59] based on unmanaged ecosystems found that $\mathrm{N}$ application can suppress soil microbiota. However, the responsiveness of the microorganisms in the agricultural land is expected to differ from natural ecosystems. In an agricultural land, the $\mathrm{N}$ concentration surpasses the amount of $\mathrm{N}$ in a natural 
ecosystem due to large application of the fertilizer during the year. High application rates of $\mathrm{N}$ fertilizers can temporarily increase levels of osmotic potential, furthermore, some concentrations of $\mathrm{N}$ forms can be potentially toxic [60]. Additionally, increased application of $\mathrm{N}$ fertilizers is known to cause $\mathrm{pH}$ changes in the agricultural soils which strongly influence microbial composition [61]. Fierrer and Jackson [62] found (using ribosomal DNA-fingerprinting) that in 98 samples of soil collected from North and South America, microbial diversity was not related to temperature, latitude and other factors that usually affect plant and animal diversity. The diversity and richness of soil microbial communities depend mostly on the ecosystem type, and the differences between ecosystems are greatly related to soil $\mathrm{pH}$. Generally, it was observed that bacterial diversity was higher in neutral soils and lower in acidic soils. The nitrogen fertilizer application was reported in many long-term field experiments to significantly acidify and change the soil chemical properties [63] [64] [65]. For example, Juo and coworkers [66] demonstrated that ammonium sulfate decreased soil pH from 5.8 to 4.5 during five years of continuous maize cropping. To prevent acidification of agricultural soil and thereby protect soil microorganisms from the stress conditions, common agricultural treatment such as liming is recommended. In tempered climate it can raise the soil $\mathrm{pH}$ into the range of 5.7 to 6.5 ; additionally lime application is considered to have beneficial effects on the soil physical conditions [67].

Geisseler and Scow [61] in their meta-analysis review reported that mineral fertilization significantly increased soil organic carbon $\left(C_{\text {org }}\right)$ content compared to untreated control, by an average of $12.8 \%$. It is explained by the increased plant productivity caused by the use of fertilizers in agricultural systems which increases organic material such as aboveground residues, decomposing roots and exudates which constitute a great source of $\mathrm{C}$ available for soil microorganisms. In the same study it was found that mineral fertilizers tend to decrease $\mathrm{qCO}_{2}$ level and significantly increase enzymatic activity of $\beta$-glucosidase and acid phosphatase. Also, microbial carbon biomass $\left(C_{\text {mic }}\right)$ was significantly higher (15.1\%) compared to unfertilized plots. It is believed that the major factor contributing to the overall increase in $C_{\text {mic }}$ and enzyme activity is the result of higher content of $C_{\text {org }}$. Nonetheless, when the fertilizer decreases soil $\mathrm{pH}$ below certain level $C_{\text {mic }}$ does not respond to the fertilizer or may even be reduced.

In recent years, biochar has gained importance as a way to deal with global climate changes, by sequestering $\mathrm{C}$ into soils, but also as a soil amendment. Biochar and its highly porous structure can provide a suitable habitat for many microorganisms by protecting them from predation and desiccation, providing carbon (C) as a source of energy and mineral nutrients [68]. Glodowska et al. [69] showed that some biochars can sustain viability of plant growth promoting bacteria for more than 6 months and that biochar can be a suitable carrier for bacterial inoculation. Anderson et al. [70] using TRFLP and new generation sequencing (NGS) techniques, investigated the effect of biochar on the bacterial communities in the pot experiment. The study revealed that biochar amended 
soil positively affected the abundance of Bradyrhizobiaceae ( 8\%), Hyphomicrobiaceae ( $14 \%)$, Streptosporangineae $(\sim 6 \%)$ and Thermomonosporaceae $(\sim 8 \%)$ compared to the control. It is hypothesized that biochar application as a soil conditioner alter microbial communities and function mainly through changes in physicochemical properties of soil and introduction of metabolically available C-compounds [71].

Microbial inoculants and so-called bio-fertilizers are promising tools to mitigate the negative effect of mineral fertilizers on the environment due to its plant growth promoting properties and capacity to enhance nutrient availability and uptake. Although there is a lack of consistent evidence that inoculants could replace mineral fertilizers, many studies showed that they are a good supplement to mineral fertilizers [72]. Vázquez [73] found that application of microbial inoculation caused important changes in the microbial community structure in the rhizosphere as well as in the bulk soil of corn. It was shown that esterase activity was increased by G. mosseae (256\%), chitinase by G. mosseae (197\%), G. deserticola (152\%) and trehalase by $G$. deserticola (444\%) inoculation. Microorganisms from inoculants are not always able to compete with the native strains in the natural environment; hence, it is believed that bacteria isolated from the soil will perform better in a habitat similar to the one they were isolated from, since they are better adapted to ecological stresses typical for this environment. Introducing foreign microorganisms in the soil environment might bring undesirable ecological effects; therefore, it is important that the environmental fate of inoculant organisms, as well as any effects of their release, is previously assessed [74].

\section{Effect of Heavy Metals on Soil Microorganisms}

The various physiological groups of microorganisms showed a remarkable correlation with relevant soil chemical elements. Because of the agricultural treatments such as the application of sewage sludge, livestock manures, inorganic fertilizers and other agrochemicals, soils are constantly exposed to elevated concentrations of heavy metals [75]. Therefore, it is not a surprise that agricultural soils often show a higher concentration of heavy metal compared to natural, untreated lands. Soil chemical and physical properties such as $\mathrm{pH}$, clay and organic matter content can alter the effect of certain metals on soil microbiota [76]. Increased concentration of some metals has been shown to have unfavorable effects on the diversity, size, as well as the activity of microbial populations in the soil [77]. The danger comes from the fact that these elements accumulate in the soil perpetually often in toxic concentrations and cannot be degraded. $\mathrm{Cd}, \mathrm{Pb}$, $\mathrm{As}, \mathrm{Cu}, \mathrm{Ni}$ has the most deleterious effect on living organisms, including microorganisms. Donkova and Dinev [78] conducted the study on a heavily polluted area of non-ferrous metals factory where concentration of heavy metals such as $\mathrm{Cd}, \mathrm{Pb}, \mathrm{Cu}$ and $\mathrm{Zn}$ overpassed the Maximum Permitted Concentrations. The results showed that the abundance of bacteria and of the cellulose degrading mi- 
croorganisms decreased to $80 \%$, that of the actinomycetes to $50 \%$; on the other hand, a stimulating effect was observed in the case of fungi. The most common case in the arable lands is a combination of several metals together with other pollutants. Therefore, some scientists attempted to combine different factors and tried to understand the pollution complex and its influence on the soil microflora. Wang and Zhou [79] studied the combined effects of cadmium (Cd, 10 $\mathrm{mg} / \mathrm{kg}$ of soil) and herbicide of the acetanilide class, butachlor $(5,10$ and 50 $\mathrm{mg} / \mathrm{kg}$ of soil) on soil enzymatic activities (urease and phosphatase) and the microbial community structure. It was demonstrated that the effect was strongly related to the ratio of $\mathrm{Cd}$ and butachlor added to the soil. When $\mathrm{Cd}$ was applied alone, phosphatase activities in soils were decreased, whereas urease activities were insensitive to the $\mathrm{Cd}$ addition. On the other hand, phosphatase and urease activities were significantly reduced when a high butachlor concentration (50 $\mathrm{mg} / \mathrm{kg}$ of soil) was added. Maliszewska-Kordybach [80] proved that the combined effect of some polycyclic aromatic hydrocarbons (PAH) such as anthracene, flourene, chrysene and pyrene with $\mathrm{Zn}, \mathrm{Pb}$ and $\mathrm{Cd}$ can have a stronger effect on the activity of soil microorganisms than the application of these pollutants separately. It was also observed that the reaction of the tested organisms was related to the soil properties as well as the PAHs concentration.

Numerous studies showed that soil microorganisms have different sensitivity to heavy metals. The experiment where the contaminated sewage sludge was applied to the soil and then inoculated with rhizobium demonstrated that after a few weeks of inoculation, the number of $R$. leguminosarum bv. trifolii significantly decreased in the contaminated soils [81]. The same was observed with $R$. loti but a Sinorhizobium meliloti strain appeared to be considerably less sensitive to heavy metals in the soil. Although some of bacteria show resistance to the higher concentration, generally heavy metals pollution tends to reduce microbial diversity by the extinction of a particular group and enrichment of another which survives in the metal stress conditions [82]. This is considered to be true for other factors that can create stressful conditions for microorganisms, such as mineral fertilizers or different types of pesticides.

\section{Effect of Crop Rotation on Microbial Communities}

The plant and its surrounding soil create a very complex system. There is a close relationship between plants and microorganisms that allows them to coexist [83]. A lot of attention was focused on the endophytes, symbionts, plant growth promoting rhizobacteria and pathogens. However, these microorganisms are just a small portion of the whole microbiome. The remaining, unknown part of the soil microbiome is the majority of the organisms that exist in the soil system. Clearly plant diversity affects soil microbial communities by providing suitable habitat and a source of nutrients. Some microorganisms increase the availability of nutrients in the soils. The most studied example is the legumes which enhance soil quality through their symbiotic relation with nitrogen-fixing bacteria [84]. A 
number of studies suggest that the effect of aboveground vegetation is significant to soil microorganisms. Zak et al. [85] conducted a long-term field experiment focusing on plant diversity, microbial communities and their functions. It was shown that microbial community biomass, respiration, fungal abundance and $\mathrm{N}$-mineralization rate, significantly increased with greater plant diversity. Similarly, Carney and Matson [86] with the use of the PLFA method showed that plant diversity had a significant effect on the communities' composition. It was found that microbial communities' composition varied with the plant diversity gradient and this was a factor strongly related to the soil catabolic potential. Spehn et al. [87] also demonstrated that plant biodiversity affected the microbial communities. When the plant species' richness was reduced, a decrease of microbial biomass was observed. It was also noticed that the presence of specific plants communities such as legumes stimulated microbial population size and function [87] [88].

Microbial physiological groups that use specific nutrient resources are associated with specific plant species, and the rhizosphere is the most colonized region of the plant [89]. Although plants are known to have specific mycorrhizal and nodulation associations developed with the microorganisms at the level of rhizosphere, there are also other relationships at the level of the phyllosphere and endosphere. Plant rhizosphere colonization by the genera such as Rhizobium sp., Azospirillum sp., Bacillus subtilis sp., and Pseudomonas sp. has been investigated extensively and the communication patterns are already well understood [84] [90]. From an economical point of view, some of the best know and important nitrogen-fixing symbiosis occurs in the Fabaceae family, for example between soybean and Bradyrhizobium japonicum [91], common bean and Rhizobium etli [92], lentils and Rhizobium leguminosarum bv. viciae [91]. The surface properties of the root tissue, nutrient and water availability in the root exudes, metabolites and signaling compounds released by plant roots are factors that attract specific groups of soil microorganisms to the rhizosphere [93]. The range of carbon compounds, such as amino acids and sugars, released by the plant makes the rhizosphere much more abundant in the microorganisms, enhance microbial biomass and activity compared to the bulk soil [94]. For comparison rhizosphere/bulk soil ratio for bacteria, actinomycetes and fungi are commonly in the ranges $2-10,5-10$ and $10-20$, respectively [95].

Plant growth promoting rhizobacteria (PGPR) have the potential to increase plant growth by a variety of mechanisms. The most important of them are nitrogen fixation, siderophore production, phosphate solubilization as well as phytohormones production. Because of the environmental concerns the use of PGPR in agriculture is growing regularly offering some alternatives to mineral fertilizers, pesticides and other supplements [96]. Interestingly, phylogenetically distinct microbial profiles in different rhizosphere zones of the same plant are not unusual. For example, it was shown using $16 \mathrm{~S}$ rDNA profiles generated by PCR-DGGE, different root zones of the same plant can create the habitat for dis- 
tinct bacterial communities which is most probably caused by differences in quality and quantity of root exudes [97].

Like all living organisms, microorganisms need energy to conduct their basic metabolic activities. Plant exudes are usually a great source of carbon used by soil microbiota in their metabolic processes. Some of these compounds attract specific group of bacteria. Therefore, there is no surprise that crop rotation significantly influences the soil microorganisms. Bernard et al. [12] found that rapeseed green manure rotation had a great impact on soil microbial communities. It caused an increase in the total population of culturable bacteria. Also, observable shifts in microbial communities were determined by sole carbon-source substrate utilization and fatty acid methyl ester (FAME) profiles. Similarly, Hilton et al. [98] found that rapeseed rotation had a significant effect on the fungal community. Using TRFLP technique and sequencing, it was shown that continuously grown oilseed rape increased the abundance of pathogenic fungi, compared to the oilseed rape and wheat rotation. Jiang and coworkers [99] studied how crop rotation altered bacterial and fungal diversity in rice paddies. Their survey demonstrated remarkable differences in the diversity and composition of microbial operational taxonomic units (OTUs) among four different crop rotations. They also revealed that Rhizobiale bacteria (genus Bradyrhizobium) and Hypocreales fungi are the most cosmopolitan groups, found among four crop systems.

Nowadays, the transgenic plants are gaining a lot of attention; therefore, study has been conducted to evaluate the effects of the GMO and non-GMO crops on soil and rhizospheral bacteria and fungi. Milling et al. [100] recorded some differences in the microbial communities of the rhizosphere between transgenic potatoes and it parental cultivar. Similarly, Sessitsch and coworkers [101] found that rape rhizosphere bacteria were affected by genetic modification and herbicide application. However, the effect depended on the plant development stage. Vilvert et al. [102] showed significant increase in the microbial biomass carbon and the total microbial biomass in the soil where transgenic soybean was cultivated, in contrast to non-transgenic crops. Reduction in the microbial metabolic quotient $\left(\mathrm{qCO}_{2}\right)$ in the soil under transgenic crops was also observed. This evidence suggests that GMOs crops are other important aspects to consider in agricultural systems that can affect microbial communities and activities.

\section{Metagenomics-To Better Understand Soil Microbial Communities}

Metagenomics is a new field that combines elements of molecular biology and genetics which allows identifying and characterizing soil microorganisms in the soils through analyses of genetic materials isolated directly from this soil sample. Furthermore, in situ analysis of rRNA permits to identify the active taxa and mRNA allow detecting an expression of functional genes in soil which gives a complete image of the structure and function of the soil microbial communities 
[11]. Metagenomics studies are considered the most efficient way to see the complete microbiological profile of the bulk soil as well as rhizosphere [103] and the plant. Metagenomic approach allows to look at the diversity of microorganisms present in a sample and to characterize their taxonomic structure and richness. There is an increasing amount of data obtained by these techniques which give much more complete image of the soil diversity and abundance.

In a 13-year field trial in southern Brazil, Souza et al. [104] used the shotgun sequencing approach to study the effect of different soils and crop management practices on soil biodiversity. Approximately 1 million reads per treatment were obtained which revealed a very high level of diversity. This could never be achieved using classical methods.

Fierer et al. [105], using pyrosequencing-based analyses of 16S rRNA genes, revealed no significant effects of $\mathrm{N}$ fertilization on the bacterial diversity, however significant changes were observed in the bacterial community composition. For example, it was observed that the number of copiotrophic taxa (Proteobacteria and Bacteroidetes phyla) usually increased in the high $\mathrm{N}$ plots, with oligotrophic taxa (Acidobacteria) demonstrating the opposite pattern. Similarly, Carbonetto and coworkers [106], using the metagenomic approach, observed that microbiomes of cultivated soils of Argentinian Pampas presented tendencies to copiotrophy while non-cultivated soils more oligotrophic lifestyle. Furthermore, the study confirmed the hypothesis that agricultural practices such as tillage, rotation as well as $\mathrm{P}$ and $\mathrm{N}$ fertilization affect the microbial structure and composition. The phyla such as Gemmatimonadetes, Nitrospirae were more abundant in cultivated soils while Verrucomicrobia, Plactomycetes, Actinobacteria, and Chloroflexi were more abundant in non-cultivated soils. The results suggest that agronomical land use and the tillage induced the changes in the life strategies of soil microorganisms. Metagenomic data provides a great amount of information. However, the interpretation and application of this information in the agriculture are still challenging. There is no doubt that the new cutting-edge molecular techniques can help us to understand the role played by different microbial groups within various ecosystems. Knowledge of the taxonomic groups that dominate in certain types of soil or agricultural systems can be precious information and might help to follow the changes caused by the agricultural practices.

\section{Conclusions and Perspectives}

The evidence reviewed above suggests that soil microbiota is strongly affected by agricultural treatments. To maintain the fertility and productivity of the soil it is extremely important to protect not only the aboveground plant communities but also the underground microbial soil ecosystem. It is very difficult to investigate the behavior and composition of soil microorganisms in agricultural soils which are constantly disturbed and affected by different treatments. Some of them such as the application of organic amendments are known to have a positive influence 
on soil microflora. Others, when used inappropriately, cause changes in the microbial profile which can lead to serious ecological consequences. The soil system is extremely complex; therefore, it is continuous work for microbiologists to understand the function and structure of the soil microbiota and how the anthropogenic and natural occurring activities can change it. These shifts in the microbial community structure cannot be fully captured with traditional methods; however, metagenomics approaches can differentiate changes within specific groups and can improve our understanding of phylogenetic and functional changes in the soil. Molecular methods can be used in order to establish key species crucial for maintaining ecosystem services and to determine effects of agricultural treatments on the soil bacterial diversity and abundance. Metagenomic analysis of soil microbiota might be an easy tool to determine soil condition by assessment of microbial relative abundance, biodiversity and phylogenetic structure. Data generated by molecular study can provide very useful and complete information of soil microbiology that can be easily correlated to agricultural treatments as well as soil chemistry. As a result, the understanding of how agriculture affects soil microorganisms should be much easier and assessment of soil health and fertility in the context of microbial activity should be facilitated.

Although many agricultural activities cause environmental problems and are known to have negative effects on soil microorganisms, there are some practices that can help soil microbiota by creating suitable conditions. Maintaining or increasing the soil organic matter by frequent applications of organic fertilizers such as compost, farm yard manure or green manure, is an example of such practices. To reduce the negative effect of mineral fertilizer and pesticides on soil microbiota the integrated farming system is recommended, as well as alternating with microbial inoculants and bio-fertilizers. To overcome side effects of mineral fertilizers such as soil acidification, simple treatments such as lime application is recommended. Additionally, use of soil amendments such as biochar can help to maintain the bacterial abundance and activities by providing an appropriate habitat for soil microorganisms. Finally, crop rotation should be applied in all agricultural systems. It can help to maintain a high abundance as well as a diversity of microbial communities, and by growing legumes it can increase the amount of plant growth promoting rhizobacteria such as $\mathrm{N}$-fixing bacteria.

\section{Conflicts of Interest}

The authors declare no conflicts of interest regarding the publication of this paper.

\section{References}

[1] Keesstra, S., Nunes, J., Novara, A., Finger, D., Avelar, D., Kalantari, Z. and Cerdà, A. (2018) The Superior Effect of Nature-Based Solutions in Land Management for Enhancing Ecosystem Services. Science of the Total Environment, 610, 997-1009. https://doi.org/10.1016/j.scitotenv.2017.08.077 
[2] Buckley, D.H. and Schmidt, T.M. (2001) The Structure of Microbial Communities in Soil and the Lasting Impact of Cultivation. Microbial Ecology, 42, 11-21.

[3] Nielsen, S., Minchin, T., Kimber, S., Zwieten, L., Gilbertd, J., Munroe, P., Joseph, S. and Thomas, T. (2014) Comparative Analysis of the Microbial Communities in Agricultural Soil Amended with Enhanced Biochars or Traditional Fertilizers. Agriculture, Ecosystems and Environment, 191, 73-82.

https://doi.org/10.1016/j.agee.2014.04.006

[4] Hafez, H.F.H. and Theimann, W.H.P. (2003) Persistence and Biodegradation of Iazinone and Imidacloprid in Soil. XII Symposium Pesticide Chemistry, Piacenza, 2003, 35-42.

[5] Smith, S.E. and Smith, F.A. (2012) Fresh Perspectives on the Roles of Arbuscular Mycorrhizal Fungi in Plant Nutrition and Growth. Mycologia, 104, 1-13.

https://doi.org/10.3852/11-229

[6] Mohammadi, K. (2012) Phosphorus Solubilizing Bacteria, Occurrence, Mechanisms and Their Role in Crop Production. Resources and Environment, 2, 80-85.

[7] Brussaard, L. (1997) Biodiversity and Ecosystem Functioning in Soil. Ambio, 26, 563-570.

[8] Tisdall, J. (1994) Possible Role of Soil Microorganisms in Aggregation in Soils. Plant and Soil, 159, 115-121. https://doi.org/10.1007/BF00000100

[9] Susilo, F.X., Neutel, A.M., van Noordwijk, M., Hairiah, K., Brown, G. and Swift, M.J. (2004) Soil Biodiversity and Food Webs. In: van Noordwijk, M., Cadisch, G. and Ong, C.K., Eds., Below-Ground Interactions in Tropical Agroecosystems, CAB International, Wallingford, 285-302. https://doi.org/10.1079/9780851996738.0285

[10] Haas, D. and Défago, G. (2005) Biological Control of Soil-Borne Pathogens by Fluorescent Pseudomonads. Nature Reviews in Microbiology, 3, 307-319. https://doi.org/10.1038/nrmicro1129

[11] Bhat, A.K. (2013) Preserving Microbial Diversity of Soil Ecosystem: A Key to Sustainable Productivity. International Journal of Current Microbiology and Applied Sciences, 2, 85-101.

[12] Bernard, B., Larkin, R.P., Tavantzis, S., Erich, M.S., Alyokhin, A., Sewell, G., Lannan, A. and Gross, S.D. (2012) Compost, Rapeseed Rotation, and Biocontrol Agents Significantly Impact Soil Microbial Communities in Organic and Conventional Potato Production Systems. Applied Soil Ecology, 52, 21-49. https://doi.org/10.1016/j.apsoil.2011.10.002

[13] Lazcano, C., Gómez-Brandón, M. and Revilla P. (2013) Short-Term Effects of Organic and Inorganic Fertilizers on Soil Microbial Community Structure and Function. A Field Study with Sweet Corn. Biology and Fertility of Soils, 49, 723-733. DOI: https://doi.org/10.1007/s00374-012-0761-7

[14] Zhong, W., Gu, T., Wang, W., Zhang, B., Lin, X., Huang, Q. and Shen, W. (2010) The Effects of Mineral Fertilizer and Organic Manure on Soil Microbial Community and Diversity. Plant and Soil, 326, 511-522.

https://doi.org/10.1007/s11104-009-0099-6

[15] Lauber, C.L., Hamady, M., Knight, R. and Fierer, N. (2009) Pyrosequencing-Based Assessment of Soil $\mathrm{pH}$ as a Predictor of Soil Bacterial Community Structure at the Continental Scale. Applied and Environmental Microbiology, 75, 5111-5120. https://doi.org/10.1128/AEM.00335-09

[16] Gans, J., Woilinsky, M. and Dunbar, J. (2005) Computational Improvements Reveal Great Bacterial Diversity and High Metal Toxicity in Soil. Science, 309, 1387-1390. https://doi.org/10.1126/science.1112665 
[17] Bell, T., Newman, J.A., Silverman, B.W., Turner S.L. and Lilley, A.K. (2005) The Contribution of Species Richness and Composition to Bacterial Services. Nature, 436, 1157-1160. https://doi.org/10.1038/nature03891

[18] Miller, D.N., Bryant, J.E., Madsen, E.L. and Ghiorse, W.C. (1999) Evaluation and Optimization of DNA Extraction and Purification Procedures for Soil and Sediment Samples. Applied and Environmental Microbiology, 65, 4715-4724.

[19] Kennedy, A.C. and Smith, K.L. (1995) Soil Microbial Diversity and the Sustainability of Agricultural Soils. Plant and Soil, 170, 75-86. https://doi.org/10.1007/BF02183056

[20] Martyniuk, S. and Wagner, G.H. (1978) Quantitative and Qualitative Examination of Soil Microflora Associated with Different Management Systems. Soil Science, 125, 343-350. https://doi.org/10.1097/00010694-197806000-00002

[21] Han, W., Kemmitt, S.J. and Brookes, P.C. (2007) Soil Microbial Biomass and Activity in Chinese Tea Gardens of Varying Stand Age and Productivity. Soil Biology and Biochemistry, 39, 1468-1478. https://doi.org/10.1016/j.soilbio.2006.12.029

[22] Handa, S.K., Agnihotri, N.P. and Kulshrestha, G. (1999) Maximum Residue Limits of Pesticides. In: Handa, S.K., Agnihotri, N.P. and Kulshrestha, G., Eds., Pesticide Residues Significance, Management and Analysis, Research Periodicals and Book Publishing House, Houston, 184-198.

[23] Fenner, K., Canonica, S., Wackett, L.P. and Elsner, M. (2013) Evaluating Pesticide Degradation in the Environment, Blind Spots and Emerging Opportunities. Science, 341, 752-758. https://doi.org/10.1126/science.1236281

[24] Chowdhury, A., Pradhan, S., Saha, M. and Sanya, N. (2008) Impact of Pesticides on Soil Microbiological Parameters and Possible Bioremediation Strategies. Indian Journal of Microbiology, 48,114-127. https://doi.org/10.1007/s12088-008-0011-8

[25] Moorman, T.B. and Harper, S.S. (1989) Transformation and Mineralization of Metribuzin in Surface and Subsurface Horizons of a Mississippi Delta Soil. Journal of Environmental Quality, 18, 302-306. https://doi.org/10.2134/jeq1989.00472425001800030011x

[26] Torstenssen, L. and Stenstorm, J. (1986) Basic Respiration Rate as a Tool for Prediction of Pesticide Persistence in Soil. Environmental Toxicology, 1, 57-72. https://doi.org/10.1002/tox.2540010106

[27] Voos, G. and Groffman, P.M. (1997) Relationship between Microbial Biomass and Dissipation of 2, 4-D and Dicamba in Soil. Biology and Fertility of Soils, 24, 106-110. https://doi.org/10.1007/BF01420229

[28] Walker, A., Moon, Y.H. and Welch, S.J. (1992) Influence of Temperature, Soil Moisture and Soil Characteristics on Persistence of Alachlor. Journal of Pest Science, 35,109-116. https://doi.org/10.1002/ps.2780350203

[29] Anderson, J.P.E. (1981) Methods to Evaluate Pesticide Damage to the Biomass of the Soil Microflora. Soil Biology and Biochemistry, 13, 149-153. https://doi.org/10.1016/0038-0717(81)90011-0

[30] Duah-Yentumi, S. and Johnson, D.B. (1986) Changes in Soil Microflora in Response to Repeated Applications of Some Pesticides. Soil Biology and Biochemistry, 18, 629-635. https://doi.org/10.1016/0038-0717(86)90086-6

[31] Wardle, D.A. and Parkinson, D. (1992) The Influence of the Herbicide Glyphosate on Interspecific Interactions between Four Soil Fungal Species. Mycological Research, 24, 185-186. https://doi.org/10.1016/S0953-7562(09)80963-5

[32] Perucci, P. and Scarponi, L. (1994) Effects of the Herbicide Imazethapyr on Soil 
Microbial Biomass and Various Soil Enzyme Activities. Biology and Fertility of Soils, 17, 237-240. https://doi.org/10.1007/BF00336329

[33] Rath, A.K., Ramakrishnan, B., Kumaraswamy, S., Bharati, K., Singla, P. and Sethunathan, N. (1998) Effect of Pesticides on Microbial Biomass of Flooded Soil. Chemosphere, 37, 661-671. https://doi.org/10.1016/S0045-6535(98)00082-4

[34] Vischetti, C., Perucci, P. and Scarponi, L. (2000) Relationship between Rimusulfuron Degradation and Microbial Biomass Content in a Clay Loam Soil. Biology and Fertility of Soils, 31, 310-314. https://doi.org/10.1007/s003740050661

[35] Araújo, A.S.F., Monterio, R.T.R. and Abarkeli, R.B. (2003) Effect of Glyphosate on the Microbial Activity of Two Brazilian Soils. Chemosphere, 52, 799-804. https://doi.org/10.1016/S0045-6535(03)00266-2

[36] Lundgren, B. (1981) Fluorescein Diacetate as a Stain of Metabolically Active Bacteria in Soil. Oikos, 36, 17-22. https://doi.org/10.2307/3544373

[37] Zelles, L., Scheunert, I. and Korte, F. (1985) Side Effects of Some Pesticides on Non-Target Soil Microorganisms. Journal of Environmental Science and Health, 20, 457-488. https://doi.org/10.1080/03601238509372489

[38] Pankhurst, C.E., Hawke, B.A., McDonald, H.J., Kirby, C.A., Buckerfield, J.C., Michelsen, P.U., Brien, K.A., Gupta, V.V.S.R. and Doube, B.M. (1995) Evaluation of Soil Biological Properties as Potential Bioindicators of Soil Health. Australian Journal of Experimental Agriculture, 35, 1015-1028. https://doi.org/10.1071/EA9951015

[39] Yao, X.-H., Min, H., Lü, Z.-H. and Yuan, H.-P. (2006) Influence of Acetamiprid on Soil Enzymatic Activities and Respiration. European Journal of Soil Biology, 42, 120-126. https://doi.org/10.1016/j.ejsobi.2005.12.001

[40] Bartha, R., Lanzilotta, R.P. and Pramer, D. (1967) Stability and Effects of Some Pesticides in Soil. Journal of Applied Microbiology, 15, 67-75.

[41] Tu, C.M. (1992) Effect of Some Herbicides on Activities of Microorganisms and Enzymes in Soil. Journal of Environmental Science and Health, 27, 695-709. https://doi.org/10.1080/03601239209372807

[42] Haney, R.L., Senseman, S.A., Hons, F.M. and Zuberer, D.A. (2000) Effect of Glyphosate on Soil Microbial Activity and Biomass. Weed Science, 48, 89-93.

[43] Gomez, E., Ferreras, L., Lovotti, L. and Fernandez, E. (2009) Impact of Glyphosate Application on Microbial Biomass and Metabolic Activity in a Vertic Argiudoll from Argentina. European Journal of Soil Biology, 45, 163-167. https://doi.org/10.1016/j.ejsobi.2008.10.001

[44] Sebiomo, A., Ogundero, V.W. and Bankole, S.A. (2011) Effect of Four Herbicides on Microbial Population, Soil Organic Matter and Dehydrogenase Activity. African Journal of Biotechnology, 10, 770-778.

[45] Milenkovski, S., Bååth, E., Lindgren, P.E. and Berglund, O. (2010) Toxicity of Fungicides to Natural Bacterial Communities in Wetland Water and Sediment Measured Using Leucine Incorporation and Potential Denitrification. Ecotoxicology, 19, 285-294. https://link.springer.com/article/10.1007/s10646-009-0411-5

[46] Zhuang, R.S., Chen, H.L., Yao, J., Li, Z., Burnet, J.E. and Choi, M.M.F. (2011) Impact of Beta-Cypermethrin on Soil Microbial Community Associated with Its Bioavailability, a Combined Study by Isothermal Microcalorimetry and Enzyme Assay Techniques. Journal of Hazardous Materials, 189, 323-328. https://doi.org/10.1016/j.jhazmat.2011.02.034

[47] Goswami, M.R., Pati, U.K., Chowdhury, A. and Mukhopadhyay, A. (2013) Studies 
on the Effect of Cypermethrin on Soil Microbial Biomass and Its Activity in an Alluvial Soil. Journal of the Science of Food and Agriculture, 3, 1-9.

[48] Beelen, P.V. and Doelman, P. (1997) Significance and Application of Microbial Toxicity Tests in Assessing Ecotoxicological Risks of Contaminants in Soil and Sediment. Chemosphere, 34, 455-499. https://doi.org/10.1016/S0045-6535(96)00388-8

[49] Anderson, T.H. and Domsch, K.H. (1990) Application of Ecophysiological Quotients $\left(q \mathrm{CO}_{2}\right.$ and $q \mathrm{D}$ ) on Microbial Biomass from Soils of Different Cropping Histories. Soil Biology and Biochemistry, 22, 251-255. https://doi.org/10.1016/0038-0717(90)90094-G

[50] Jones, W.J. and Ananyeva, N.D. (2001) Correlations between Pesticide Transformation Rate and Microbial Respiration Activity in Soil of Different Ecosystems. Biology and Fertility of Soils, 33,477-483. https://doi.org/10.1007/s003740100365

[51] Moreno, J.L., Aliaga, A., Navarro, S., Hernandez, T. and Garcia, C. (2007) Effects of Atrazine on Microbial Activity in Semiarid Soil. Applied Soil Ecology, 35, 120-127. https://doi.org/10.1016/j.apsoil.2006.05.002

[52] Zhang, B.G., Bai, Z.H., Hoefel, D., Tang, L., Wang, X.Y., Li, B.J., Li, Z.M. and Zhuang, G.Q. (2009) The Impacts of Cypermethrin Pesticide Application on the Non-Target Microbial Community of the Pepper Plant Phillosphere. Science of the Total Environment, 407, 1915-1922. https://doi.org/10.1016/j.scitotenv.2008.11.049

[53] Bælum, J., Nicolaisen, M.H., Holben, W.E., Strobel, B.W., Sørensen, J. and Jacobsen, C.S. (2008) Direct Analysis of tfdA Gene Expression by Indigenous Bacteria in Phenoxy Acid Amended Agricultural Soil. The ISME Journal, 2, 677-687. https://doi.org/10.1038/ismej.2008.21

[54] Savci, S. (2012) An Agricultural Pollutant: Chemical Fertilizer International. Journal of Environmental Science and Development, 3, 77-80.

[55] Swift, M.J., Heal, O.J. and Anderson, J.M. (1979) Decomposition in Terrestrial Ecosystems. Blackwell, Oxford.

[56] Bhoi, L. and Mishra, P.C. (2012) Changes in Bacterial Density, $\mathrm{CO}_{2}$ Evolution and Enzyme Activities in Poultry Dung Amended Soil. Open Journal of Soil Science, 2, 196-201. https://doi.org/10.4236/ojss.2012.22024

[57] Bol, R., Kandeler, E., Amelung, W., Glaser, B., Marx, M.C., Preedy, N. and Lorenz, K. (2003) Short-Term Effects of Dairy Slurry Amendment on Carbon Sequestration and Enzyme Activities in a Temperate Grassland. Soil Biology and Biochemistry, 35, 1411-1421. https://doi.org/10.1016/S0038-0717(03)00235-9

[58] Allison, S.D. and Martiny, J.B.H. (2008) Resistance, Resilience, and Redundancy in Microbial Communities. Proceedings of the National Academy of Sciences of the United States of America, 105, 11512-11519. https://doi.org/10.1073/pnas.0801925105

[59] Treseder, K.K. (2008) Nitrogen Additions and Microbial Biomass: A Meta-Analysis of Ecosystem Studies. Ecology Letters, 11, 1111-1120. https://doi.org/10.1111/j.1461-0248.2008.01230.x

[60] Omar, S.A. and Ismail, M. (1999) Microbial Populations, Ammonification and Nitrification in Soil Treated with Urea and Inorganic Salts. Folia Microbiologica, 44, 205-212. https://doi.org/10.1007/BF02816244

[61] Geisseler, D. and Scow, K.M. (2014) Long-Term Effects of Mineral Fertilizers on Soil Microorganisms-A Review. Soil Biology and Biochemistry, 75, 54-63. https://doi.org/10.1016/j.soilbio.2014.03.023

[62] Fierer, N. and Jackson, R.B. (2006) The Diversity and Biogeography of Soil Bacterial 
Communities. Proceedings of the National Academy of Sciences, 103, 626-631. https://doi.org/10.1073/pnas.0507535103

[63] Russell, A.E.L.D. (2006) Nitrogen Fertilization and Cropping System Impacts on Soil Quality in Midwestern Mollisols. Soil Science Society of America Journal, 1, 249-255. https://doi.org/10.2136/sssaj2005.0058

[64] Zhou, J., Xia, F., Liu, X.M., He, Y., Xu, J.M. and Brookes, P.C. (2014) Effects of Nitrogen Fertilizer on the Acidification of Two Typical Acid Soils in South China. Journal of Soils and Sediments, 14, 415-422. https://doi.org/10.1007/s11368-013-0695-1

[65] Vieira, F., Bayer, C., Mielniczuk, J., Zanatta, J. and Bissani, C.A. (2008) Long-Term Acidification of a Brazilian Acrisol as Affected by No Till Cropping Systems and Nitrogen Fertilizer. Australian Journal of Soil Research, 46, 17-26. https://doi.org/10.1071/SR07088

[66] Juo, A.S.R., Dabiri, A. and Franzluebbers, K. (1995) Acidification of a Kaolinitic Alfisol under Continuous Cropping with Nitrogen Fertilization in West Africa. Plant and Soil, 171, 245-253. https://doi.org/10.1007/BF00010278

[67] Haynes, R.J. and Naidu, R. (1998) Influence of Lime, Fertilizer and Manure Applications on Soil Organic Matter Content and Soil Physical Conditions: A Review. Nutrient Cycling in Agroecosystems, 51, 123-137. https://doi.org/10.1023/A:1009738307837

[68] Saito, M. and Marumoto, T. (2002) Inoculation with Arbuscular Mycorrhizal Fungi: the Status Quo in Japan and the Future Prospects. In: Diversity and Integration in Mycorrhizas, Springer, Dordrecht, 273-279.

https://doi.org/10.1007/978-94-017-1284-2_27

[69] Glodowska, M., Husk, B., Schwinghamer, T. and Smith, D. (2016) Biochar Is a Growth-Promoting Alternative to Peat Moss for the Inoculation of Corn with a Pseudomonad. Agronomy for Sustainable Development, 36, 21. https://doi.org/10.1007/s13593-016-0356-Z

[70] Anderson, C.R., Condrona, L.M., Clough, T., Fiers, M., Stewart, A., Hill, R.A. and Sherlock, R.R. (2011) Biochar Induced Soil Microbial Community Change: Implications for Biogeochemical Cycling of Carbon, Nitrogen and Phosphorus. Pedobiologia, 54, 309-320. https://doi.org/10.1016/j.pedobi.2011.07.005

[71] Zimmerman, A.R. (2010) Abiotic and Microbial Oxidation of Laboratory-Produced Black Carbon (Biochar). Environmental Science \& Technology, 44, 1295-1301. https://doi.org/10.1021/es903140c

[72] Adesemoye, A.O., Torbert, H.A. and Kloepper, J.W. (2009) Plant Growth-Promoting Rhizobacteria Allow Reduced Application Rates of Chemical Fertilizers. Microbial Ecology, 85, 1-12. https://doi.org/10.1007/s00248-009-9531-y

[73] Vázquez, M.M., César, S., Azcón, R. and Barea, R.M. (2000) Interactions between Arbuscular Mycorrhizal Fungi and Other Microbial Inoculants (Azospirillum, Pseudomonas, Trichoderma) and Their Effects on Microbial Population and Enzyme Activities in the Rhizosphere of Maize Plants. Applied Soil Ecology, 15, 261-272. https://doi.org/10.1016/S0929-1393(00)00075-5

[74] Elsas, J.D., Duarte, G.F., Rosado, A.S. and Smalla, K. (1998) Microbiological and Molecular Biological Methods for Monitoring Microbial Inoculants and Their Effects in the Soil Environment. Journal of Microbiological Methods, 32, 133-154. https://doi.org/10.1016/S0167-7012(98)00025-6

[75] Nicholson, F.A., Smith, S.R., Alloway, B.J., Carlton-Smith, C. and Chambers, B.J. (2003) An Inventory of Heavy Metals Inputs to Agricultural Soils in England and 
Wales. Science of the Total Environment, 311, 205-219. https://doi.org/10.1016/S0048-9697(03)00139-6

[76] Babich, H. and Stotzky, G. (1980) Environmental Factors That Influence the Toxicity of Heavy Metal and Gaseous Pollutants to Microorganisms. RC Critical Reviews in Microbiology, 8, 99-145. https://doi.org/10.3109/10408418009081123

[77] Donkova, R. and Kaloyanova, N. (2008) The Impact of Soil Pollutants on Soil Microbial Activity. In: Simeonov, L. and Sargsyan, V., Eds., Soil Chemical Pollution, Risk Assessment, Remediation and Security, NATO Science for Peace and Security Series, Springer, Dordrecht.

[78] Donkova, R. and Dinev, N. (2006) Microbiological Characteristic of Soils in the Area of Nonferrous Metals Factory, Town of Plovdiv, Bulgaria. 11 th Congress of the Microbiologists in Bulgaria, Varna, 2006.

[79] Wang, M. and Zhou, Q. (2006). Effects of Herbicide Chlorimuron-Ethyl on Physiological Mechanisms in Wheat (Triticum aestivum). Ecotoxicology and Environmental Safety, 64, 190-197. https://doi.org/10.1016/j.ecoenv.2005.03.032

[80] Maliszewska-Kordybach, B. and Smreczak, B. (2003) Habitat Function of Agricultural Soils as Affected by Heavy Metals and Polycyclic Aromatic Hydrocarbons Contamination. Environment International, 28, 719-728. https://doi.org/10.1016/S0160-4120(02)00117-4

[81] Giller, K.E., Nussbaum, R., Chaudri, A.M. and McGrath, S.P. (1993) Rhizobium meliloti Is Less Sensitive to Heavy Metal Contamination in Soil than R. leguminosarum bv. trifolii or R. loti. Soil Biology and Biochemistry, 25, 273-278. https://doi.org/10.1016/0038-0717(93)90039-E

[82] Giller, K.E., Witter, E. and Mcgrath, S.P. (1998) Toxicity of Heavy Metals to Microorganisms and Microbial Processes in Agricultural Soils: A Review. Soil Biology and Biochemistry, 30, 1389-1414. https://doi.org/10.1016/S0038-0717(97)00270-8

[83] Nihorimbere, V., Ongena, M., Smargiassi, M. and Thonart, P. (2011) Beneficial Effect of the Rhizosphere Microbial Community for Plant Growth and Health. Biotechnology, Agronomy, Society and Environment, 15, 327-337.

[84] Steenhoudt, O. and Vanderleyden, J. (2000) Azospirillum, a Free-Living Nitrogen-Fixing Bacterium Closely Associated with Grasses: Genetic, Biochemical and Ecological Aspects. FEMS Microbiology Reviews, 24, 487-506. https://doi.org/10.1016/S0168-6445(00)00036-X

[85] Zak, D.R., Holmes, W.E., White, D.C., Peascock A.D. and Tilman, D. (2003) Plant Diversity, Soil Microbial Communities and Ecosystem Function: Are There Any Links? Ecology, 84, 2042-2050. https://doi.org/10.1890/02-0433

[86] Carney, K.M. and Matson, P.A. (2005) Plant Communities, Soil Microorganisms, and Soil Carbon Cycling: Does Altering the World Belowground Matter to Ecosystem Functioning? Ecosystems, 8, 928-940.

https://doi.org/10.1007/s10021-005-0047-0

[87] Spehn, E.M., Joshi, J., Schmid, B., Alphei, J. and Körner, C. (2000) Plant Diversity Effects on Soil Heterotrophic Activity in Experimental Grassland Ecosystems. Plant and Soil, 224, 217-230. https://doi.org/10.1023/A:1004891807664

[88] Scherer-Lorenzen, M., Palmborg, C., Prinz, A. and Schulze, E.D. (2003) The Role of Plant Diversity and Composition for Nitrate Leaching in Grasslands. Ecology, 84, 1539-1552. https://doi.org/10.1890/0012-9658(2003)084[1539:TROPDA]2.0.CO;2

[89] Wardle, D.A., Bardgett, R.D. and Klironomos, J.N. (2004) Ecological Linkages be- 
tween Aboveground and Belowground Biota. Science, 304, 1629-1633.

https://doi.org/10.1126/science.1094875

[90] Trivedi, P., Pandey, A. and Palni, L.M.S. (2005) Carrier-Based Preparations of Plant Growth-Promoting Bacterial Inoculants Suitable for Use in Cooler Regions. World Journal of Microbiology and Biotechnology, 21, 941-945. https://doi.org/10.1007/s11274-004-6820-y

[91] Jordan, D.C. (1984) Family III. Rhizobiaceae Conn 1938. In: Krieg, N.R. and Holt, J.C.., Eds., Bergey's Manual of Systematic Bacteriology, Williams and Wilkins, Baltimore, ND.

[92] Segovia, L., Young, J.P.W. and Martinez-Romero, E. (1993) Reclassification of American Rhizobium leguminosarum Biovar Phaseoli Type 1 Strains as Rhizobium etli sp. nov. International Journal of Systematic and Evolutionary Microbiology, 43, 374-377.

[93] Morgan, J.A.W., Bending, G.D. and White, P.J. (2005) Biological Costs and Benefits to Plant-Microbe Interactions in the Rhizosphere. Journal of Experimental Botany, 56, 1729-1739. https://doi.org/10.1093/jxb/eri205

[94] Bending, G.D. (2003) The Rhizosphere and Its Microorganisms. In: Thomas, B., Murphy, D.J. and Murray, B.G., Eds., Encyclopaedia of Applied Plant Sciences, Academic Press, London, 1123-1129. https://doi.org/10.1016/B0-12-227050-9/00044-2

[95] Brimecombe, M.J., De Leij, F.A. and Lynch, J.M. (2001) The Effect of Root Exudates on Rhizosphere Microbial Populations. In: Pinto, R., Varanini, Z. and Nannipierei, P., Eds., The Rhizosphere, Marcel Dekker, New York, 95-141.

[96] Bhattacharyya, P.N. and Jha, D.K. (2011) Plant Growth-Promoting Rhizobacteria (PGPR): Emergence in Agriculture. World Journal of Microbiology and Biotechnology, 28, 1327. https://doi.org/10.1007/s11274-011-0979-9

[97] Yang, C.H., Crowley, D.E. and Menge, J.A. (2001) 16S rDNA Fingerprinting of Rhizosphere Bacterial Communities Associated with Healthy and Phytophthora Infected Avocado Roots. FEMS Microbiology Ecology, 35, 129-136. https://doi.org/10.1111/j.1574-6941.2001.tb00796.x

[98] Hilton, S., Bennett, A.J., Keane, G., Bending, G.D., Chandler, D., Stobart, R. and Mills, P. (2013) Impact of Shortened Crop Rotation of Oilseed Rape on Soil and Rhizosphere Microbial Diversity in Relation to Yield Decline. PLOS ONE, 8, e59859. https://doi.org/10.1371/journal.pone.0059859

[99] Jiang, Y.J., Liang, Y.T., Li, C.M., Wang, F., Sui, Y.Y., Suvannang, N., Zhou, J.Z. and Sun, B. (2016) Crop Rotations Alter Bacterial and Fungal Diversity in Paddy Soils across East Asia. Soil Biologyand Biochemistry, 95, 250-261. https://doi.org/10.1016/j.soilbio.2016.01.007

[100] Milling, A., Smalla, K, Maidl, F.X., Schloter, M. and Munch, J.C. (2004) Effects of Transgenic Potatoes with an Altered Starch Composition on the Diversity of Soil and Rhizosphere Bacteria and Fungi. Plant Soil, 266, 23-39. https://doi.org/10.1007/s11104-005-4906-4

[101] Sessitsch, A., Gyamfi, S., Tscherko, D., Gerzabek, M.H. and Kandeler, E. (2005) Activity of Microorganisms in the Rhizosphere of Herbicide Treated and Untreater Transgenic Glufosinate-Tolerant and Wildtype Oilseed Rape Grown in Containment. Plant Soil, 266, 105-116. https://doi.org/10.1007/s11104-005-7077-4

[102] Vilvert, R.M., Aguiar, D., Gimenes, T.R.M. and Alberton, O. (2014) Residual Effect of Transgenic Soybean in Soil Microbiota. African Journal of Agricultural Research, 9, 2369-2376. https://doi.org/10.5897/AJAR2013.8264 
[103] Lagos, L., Maruyama, F., Nannipieri, P., Mora, M.L., Ogram, A. and Jorquera, M.A. (2015) Current Overview on the Study of Bacteria in the Rhizosphere by Modern Molecular Techniques, a Mini-Review. Journal of Soil Science and Plant Nutrition, 15, 504-523.

[104] Souza, R.C., Cantãoc, M.E., Ribeiro Vasconcelos, A.M., Nogueira, M.A. and Hungri M. (2013) Soil Metagenomics Reveals Differences under Conventional and No-Tillage with Crop Rotation or Succession. Applied Soil Ecology, 72, 49-61. https://doi.org/10.1016/j.apsoil.2013.05.021

[105] Fierer, N., Lauber, C.L., Ramirez, K.S., Zaneveld, J., Bradford, M.A. and Knight, R. (2012) Comparative Metagenomic, Phylogenetic and Physiological Analyses of Soil Microbial Communities Across Nitrogen Gradients. The ISME Journal, 6, 1007-1017. https://doi.org/10.1038/ismej.2011.159

[106] Carbonetto, B., Rascovan, N., Álvarez, R., Mentaberry, A. and Vázquez, M.P. (2014) Structure, Composition and Metagenomic Profile of Soil Microbiomes Associated to Agricultural Land Use and Tillage Systems in Argentine Pampas. PloS ONE, 9, e99949. https://doi.org/10.1371/journal.pone.0099949 